MAKÜ Sag. Bil. Enst. Derg. 2018, 6(1): 43-50.

DERLEME/REVIEW

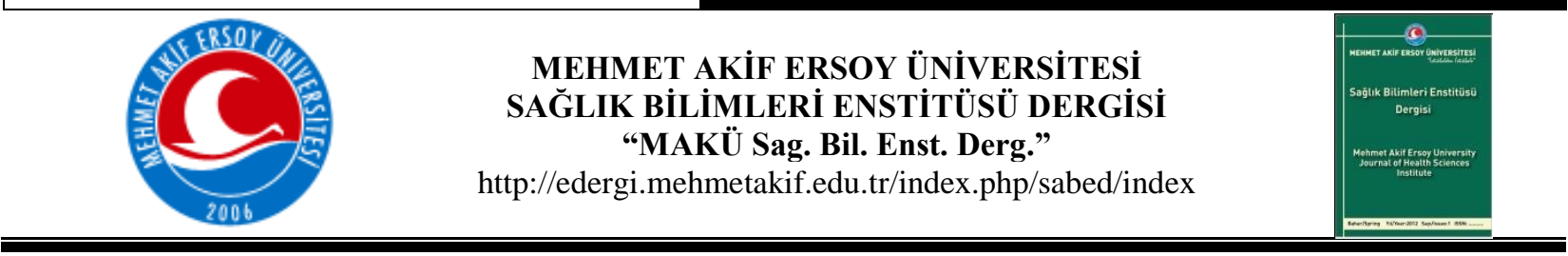

\title{
Köpeklerde Diabetes Mellitus
}

\author{
Diabetes Mellitus in Dogs
}

\author{
Nilay Vurkaç ${ }^{1}$, Şima Şahinduran² \\ ${ }^{1}$ Konyaaltı Belediyesi Veteriner İșleri Müdürlüğü, ANTALYA, TÜRKIYE \\ ${ }^{2}$ Mehmet Akif Ersoy Üniversitesi, Veteriner Fakültesi, İç Hastalıkları Anabilim Dalı, BURDUR, TÜRKIYE
}

\begin{abstract}
In 1764, Thomas Willis by tasting the patient' urine, determinated that the patient's urine containing sugar and named the disease diabetes mellitus. Diabetes mellitus is an endocrine disorder that often seen in dogs. Depending on the severity of the metabolic disorder, the disease can be asymptomatic or can be characterized by clinical symptoms such as polydipsia, polyuria, polyphagia, weight loss and weakness that affects many organs and systems.

In this review, the classification of diabetes mellitus in dogs, etiology, pathogenesis, clinical findings, laboratory findings, diagnosis and treatment are evaluated.
\end{abstract}

Key words: Diabetes Mellitus, dog, diagnosis.

Yazışma Adresi: Prof. Dr. Şima ŞAHİNDURAN

Mehmet Akif Ersoy Üniversitesi, Veteriner Fakültesi, İç Hastalıkları Anabilim Dalı, 15030, BURDUR, TÜRKIYE

Tel: (0248) 2132202

E-posta: sahinduran@mehmetakif.edu.tr

Kaynak göstermek için: Vurkaç N, Şahinduran Ş. 2018. Köpeklerde Diabetes Mellitus. MAKÜ Sag. Bil. Enst. Derg. 6(1): 43-50. doi: $10.24998 /$ maeusabed. 329298
Öz: Şeker hastalarında idrarın şeker içerdiğini tadarak belirleyen Thomas Willis 1764'de bu hastalığa Diabetes mellitus adını vermiştir. Diabetes mellitus köpeklerde sık görülen endokrin bir hastalıktır. Metabolizmada gelişen bozuklukların şiddetine bağlı olarak asemptomatik olabildiği gibi polidipsi, poliüri, polifaji, kilo kaybı ve güçsüzlük gibi klinik semptomlarla da karakterize olan hastalık birçok organ ve sistemi etkilemektedir. $\mathrm{Bu}$ derlemede köpeklerde karşılaşılan diabetes mellitustaki sınıflandırma, etiyoloji, patogenez, klinik bulgular, laboratuvar bulguları, tanı ve sağaltım aktarılmaktadır.

Anahtar sözcükler: Diabetes Mellitus, köpek, tan1.

Geliş Tarihi: 18.07.2017 Kabul Tarihi: 30.04.2018 


\section{Giriş}

Diyabetin genel olarak Tip 1 ve Tip 2 olmak üzere 2 tipi vardır. Pankreastaki $\beta$ hücrelerinin immunolojik hasarı sonucu insüline bağımlı diyabet olarak adlandırılan Tip 1 diyabet oluşur. Tip 2 (insülin bağımlı olmayan diyabet) diyabetin etiyolojisinde ise pankreastaki hücrelerde amiloid birikimi vardır ve genelde yaşlılarda gelişir. Bu iki diyabet tipinin yanında gebeliğin seyri sırasında oluşan gebelik diyabeti (gestasyonel) ve bazı hastalık ya da koşullara bağlı olarak gelişen (sekonder) diyabette vardır. Köpeklerde Tip 1 ve Tip 2 diyabet görülmektedir (Hoenig, 2002).

Diyabet genelde orta yaşlı ve yaşlı köpeklerde görülmektedir. Hastalığın insidensi 7-9 yaş arası köpeklerde en yüksektir. Pulik, Cairn terrier, Pinscher, Poodle, Beagle ve Miniature schnauzer gibi bazı köpek ırklarında hastalık daha fazla görülmektedir. Cinsiyette köpeklerde önemlidir. Dişilerde erkeklere göre 2 misli daha fazla oranda hastalık gelişir (Nelson, 1995).

\section{Sinıflandırma}

Sınıflandırma sistemi 1979 'da geliştirilmiş ve 1985 'te revize edilmiştir. Son klasifikasyon sistemine göre 4 tip diabet vardır (Stogdale, 1986).

\section{Tip I ( İnsuline bağımlı diabetes mellitus)}

$\mathrm{Bu}$ diyabet tipinde $\beta$-hücrelerine karşı immunolojik aktivite artışı vardır. $\mathrm{Bu}$ artış sonucunda ß-hücrelerine karşı oluşan antikorlarla hücreler tahrip olurlar. Köpeklerde en sık görülen bu diyabet tipinde hafif olgularda pankreastaki Langerhans adacıklarındaki ßhücrelerinde yıkımlanma ve degranülasyon sonucu hücrelerin sayı ve büyüklüğü azalmış iken şiddetli olgularda hücre saptanamayacak kadar aşırı bir hasar vardır (Fraser, 1986). Diyabetli köpeklerin \%50'sinde $\beta$ - hücrelerine karşı antikor geliştiği ve otoimmun hasar olduğu görülmüştür (Rand ve ark. 2004).

\section{Tip II (İnsuline bağımlı olmayan diabetes mellitus)}

Kedilerde görülen en yaygın diyabet tipidir (Rand ve Marshall, 2005). Tip 2 diyabette pankreas makroskopik olarak normaldir ancak Langerhans adacıklarındaki ß-hücrelerinde mikroskopik dejeneratif lezyonlar vardır. Diyabetli çoğu kedide bu dejeneratif değişikliklerle birlikte adacıklarda amiloid birikimi en karakeristik bulgudur (Başoğlu ve Sevinç, 2004; Fraser, 1986). Hedef dokularda insülin direnci ve pankreastan anormal insülin sekresyonu vardır (Ersöz, 1990; Rand ve ark. 2004). Bu diyabet şeklinde insülin salınımında hem noksanlık hem de artış olabilmektedir. Hastalığın erken döneminde aşırı insülin salınımı 
olmakta ancak kan glikoz konsantrasyonu normal seviyelerde kalmaktadır. Hastalığın ilerleyen dönemlerinde ise, insülin sekresyonunun kan glikoz konsantrasyonunu dengelemede yetersiz kalması sonucu hiperglisemi şekillenir. Gelişen hiperglisemi sonucu ß-hücrelerinin sürekli ve şiddetli olarak uyarılması sonucu bu hücrelerde fonksiyon kaybı şekillenir ve yeterli miktarda insülin salgılanamaz (Aytuğ, 2011; Martin ve Rand, 2000).

\section{Tip III gestasyonel diabet ( Gebelik diabeti)}

Köpeklerde gebelik diyabeti nadir karşılaşılan bir vakadır. Genellikle gebeliğin 2 . yarısında, ağırlıklı olarak da orta yaşlı köpeklerde gözlenmektedir. Diyabet gebelik veya diöstrüs sona erdikten sonra da devam ederse, Tip 1 diyabet ya da başka bir spesifik tanı olarak sınıflandırılmalıdır. Köpeklerde yapılan klinik çalışmalarda kışın yaşanan gebeliklerde diyabet olgusuyla daha fazla karşılaşılmıştır (Hoenig, 2002).

\section{Tip IV sekonder diabetes mellitus}

Başka hastalık ya da etmenlere bağlı olarak gelişen diyabet tipidir. Köpeklerde görülen sekonder diyabet olgularına en çok hiperadrenokortikosizm ve progesteron etkili büyüme hormonu bozuklukları gibi endokrin hastalıklar seyri sırasında rastlanılmaktadır. Akut pankreatitis vakalarının yaklaşık \%15'inde sekonder diyabet geliştiği bildirilmiştir (Fleeman ve Rand, 2001).

\section{Etiyoloji}

Diabetes mellitus hastalığının oluşmasında genetik ve çevresel faktörlerin etkisi önemli etkisi vardır (Ersöz, 1990; Schaer, 2003; Turgut, 2000). Diabetes mellitus daha çok, orta yaş veya daha yaşlı köpeklerde görülmesine rağmen yavru köpeklerde de nadiren görülebilmektedir. Hastalığın insidansı köpeklerde yaklaşık olarak \%0,2'dir ve dişilerde erkeklere göre daha fazla hastalık oluşmaktadır (Fraser, 1986; Karagül ve ark. 2000; Catchpole ve ark. 2005). Genetik faktörlerin yanı sıra diyet, hareketsizlik, çeşitli ilaçlar (Rand ve Marshall, 2005) ve özellikle obesite hastalığın oluşumunda etkilidir (Lutz ve Rand, 1995; Elliott ve ark. 1997; Lust, 2002; Rand ve ark. 2004). Bu hastalığın etiyolojisinde esas olarak pankreatitis sorumlu olup yang1, neoplazi, travma, enfeksiyon ve otoimmun hasarlarda etiyoloji de rol oynayabilmektedir (Fraser, 1986; Stogdale, 1986; Nelson, 1995). Langerhans adacıklarındaki ß-hücreleri köpeklerde şiddetli pankreatitis, kedilerde ise amiloidosis sonucu yıkımlanır ve bunun sonucunda yeteri miktarlarda insülin üretilemez. (Fraser, 1986; Fleeman ve Rand, 2001; Rand ve Marshall, 2005). Hiperadrenokortisizmli köpeklerde ise insüline 
dirençli sekonder diabetes mellitus gelişebilir. Glukokortikoid veya progestinlerin uzun süreli kullanılması da iatrojenik olarak diabetes mellitus gelişmesine sebep olabilir (Fraser, 1986). Uzun süreli steroid kullanımı glukoneogenezisi uyarır ve bunun sonucunda vücutta insülin ihtiyacı artar. Kronik olarak fazla miktarda insülin sekresyonu da ß-hücrelerinde dejenerasyona yol açar (Aytuğ, 1998). Köpeklerde progesteron hormonu hiperglisemiye sebep olan ve insülin direnci oluşturan büyüme hormonunun sekresyonuna sebep olur. Stres sonucu aşırı salınabilen epinefrin, norepinefrin, kortizol, glukagon ve ACTH gibi hormonlar da diyabeti şiddetlendirir (Bush, 1991; Özyener, 1998; Karagül ve ark. 2000). Sadece stres sonucu dahi subklinik diyabet vakaları gelişebilir. Ayrıca kanda üre seviyesinin artması da insülin ihtiyacını arttırarak diyabete sebep olabilir (Aytuğ, 1998).

\section{Patogenez}

İnsülin vücutta şeker, yağ ve protein metabolizmasında önemli rol oynamakta ayrıca karaciğer, kas, yăg dokuları üzerine de etkisi bulunmaktadır (Özyener, 1998; Guyton ve Hall, 2000; Karagül ve ark. 2000). Normalde, vücutta alınan glikozun yarısı glikolitik yolla enerjiye dönüştürülür iken diğer yarısı ise vücutta dokularda yağ veya glikojen olarak depolanmaktadır. İnsülin, kas ve yağ dokusuna glikoz girişini sağlar. İnsülin yokluğunda glikoliz azalır, glikogenez ve lipogenez de engellenir (Ersöz, 1990; Guyton ve Hall, 2000). İnsülin yetmezliği olan hastalarda lipaz aktivitesi artar bunun sonucu olarak da lipolizin hızlanması ile beraber plazma ve karaciğerde serbest yağ asidi konsantrasyonları artar (Bush, 1991; Karagül ve ark. 2000). İnsülinin ayrıca aminoasitlerin hücrelere (özellikle kas hücreleri) girişini uyarıcı etkisi de bulunmaktadır (Aytuğ, 1998; Ersöz, 1990).

\section{Klinik Bulgular}

DM terimi ile hiperglisemi ile sonuçlanan anormal karbonhidrat metabolizması ile ilişkili çoklu bir sendrom tanımlanır. Diabetik hastalardaki bireysel metabolik lezyonlar bazen insüline karşı çeşitli derecelerde gelişen periferal rezistansla birlikte relatif olarak insülin sekresyonunun baskılanmasına neden olur, bunun sonucunda da poliüri, polidipsi, polifaji ve kilo kaybı gibi karakteristik klinik bulgular gelişir.

Hiperglisemi (köpeklerde $>200 \mathrm{mg} / \mathrm{dl}$ ) tubüler reabsorbsiyon kapasitesini aştığında glukozüri şekillenir. Poliüri, glukozun böbrek tubüllerindeki osmotik diüretik etkisine bağlıdır. Polidipsi, şekillenen poliüriyi kompanze etmek için gelişir. İştah artışı, açlık 
hipotalamustaki doyma merkezi tarafindan yönetilir. Bu bölgeye glikozun girmesi için insülinin varlığı gereklidir. İnsülinin olmaması durumunda sürekli bir açlık hissi şekillenir.

İdrarla kalori kaybı nedeni ile uzun süren diyabet olgularında kilo kaybı vardır ancak bazı diyabetikler obez olabilirler.

Yağ mobilizasyonu ve hepatit lipidozis nedeniyle hepatomegali; sellüler glikoz transportunun engellenmesi nedeniyle kaslarda zayıflama; üriner ve solunum sistemi enfeksiyonları; ülseratif deri lezyonları; kutanöz ksantomatalar ve diyabetin kontrol altına alınamadığı durumlarda pankreatitits saptanır.

\section{İleri durumlarda}

Keton cisimciklerinin birikimi; metabolik asidozis dolayısıyla da depresyon; anoreksi, kusma, süratli dehidrasyon, şiddetli hipovolemi, dolaşım kollapsı sonucu, koma ve ölüm olabilir. Köpeklerin çoğunda tanıyı takiben 6 ay sonra katarakt gelişir. Hipertansiyon; glikozlu bileşiklerin endotelyumda birikmesi nedeniyle şekillenir. Ayrıca diyabetik nefropati, proteinüri, glomerulasklerozis, renal failure, diyabetik retinopati, retinal hemoraji gibi bozukluklar da şekillenebilir (Aytuğ, 2011).

\section{Laboratuvar Bulguları}

Diabetes mellitus'ta en yaygın görülen laboratuvar anormallikleri hiperglisemi, glikozüri, karaciğer enzimlerinde artış ile hiperkolesterolemi ve hiperproteinemidir. Komplikasyonlar genellikle kronik hiperglisemiye, daha az olarak da ketoasidoza bağlı olarak meydana gelir (Nelson, 1995; Elliott ve ark. 1997; Aytuğ, 1998; Fleeman ve ark. 2001; Schaer, 2003). Kan glikoz seviyesi semptomatik hastalarda genellikle $200 \mathrm{mg} / \mathrm{dl}$ 'nin üzerinde iken asemptomatik seyreden diyabet olgularında kanda glikoz düzeyi 125-180 mg/dl arasındadır (Aytuğ, 1998). Kan glikoz seviyesi böbrek eşiğini aştığında durumlarda (köpeklerde $180 \mathrm{mg} / \mathrm{dl}$, kedilerde $200 \mathrm{mg} / \mathrm{dl}$ ) glikozüri görülmekte fakat glikozüriye tüm diyabet hastalarında özellikle karbonhitrattan fakir diyetlerle beslenenlerde rastlanmaz (Bush, 1991; Aytuğ, 1998). Tip 1 Diabetes mellitus şekillenmiş vakalarda serum insülin düzeyi 26 $\mu U / m l$ 'nin altındadır (Turgut, 2000). Diyabetli hastalarda artmış yağ mobilizasyonuna bağlı olarak lipemi gelişebilir (Catchpole ve ark. 2005). Aç iken alınan örneklerde plazma bulanıktır. Kolesterol seviyesi kanda hastalığın akut safhasında 300 mg/dl civarında seyreder. Hastalık kronikleştikçe $900 \mathrm{mg}$ /dl'ye ulaşabilir. Şiddetli vakalarda kolesterol düzeyindeki artış ile birlikte kanda trigliserid, lipoprotein ve serbest yă̆ asidi seviyeleri de artar (Nelson, 
1995; Turgut, 2000; Başoğlu ve Sevinç, 2004). Hastalarda hepatik lipidozis sonucu serum ALT ve ALP aktiviteleri yükselebilir. Diabetik ketoasidozis gelişirse ketonemi ve ketonüri görülür (Lutz ve Rand, 1995; Reusch ve ark. 2006). Diabetes mellitus'ta şekillenebilen metabolik asidozis nedeni ile kan pH'sında düşüş görülür (Hoenig, 2002). Asit-baz dengesinde gelişen bu bozuklukla birlikte sıv1-elektrolit bozuklukları da görülür (Nelson, 1995). Diyabetli hayvanlarda kan üre düzeyi ile kreatinin değeri aynı zamanda primer böbrek yetmezliği olmadıkça ve prerenal üremi yoksa normaldir (Nelson, 1995; Aytuğ, 2011). Pankreatitisli köpeklerde serum lipaz ve amilaz seviyeleri yüksek saptanır. Bununla birlikte kronik yangılarda ve böbrek yetmezliği durumunda da serum amilaz ve lipaz seviyelerinin yüksek olabilir (Nelson, 1995). Diyabetli hastalarda sekonder olarak şekillenen üriner sistem enfeksiyonu sonucu idrar muayenelerinde proteinüri saptanabilir. Diyabetik hayvanlarda hiperglisemi sonucu bağırsaklardan kalsiyum emilimi azalırken, idrarla kalsiyum ve fosfor atılımı artar. Ayrıca kanda vitamin D ve osteokalsin düzeyleri de düşmekte ve bunun sonucunda da paratiroid hormon sekresyonu artmaktadır. Diyabetli hastaların hemogram sonuçları komplike olmayan vakalarda genellikle normal olmakla birlikte diyabetin hematolojik komplikasyonları sonucunda eritrosit, lökosit ile trombositlerin yapı ve fonksiyonlarında bozulmalar görülebilir (Nelson, 1995; Aytuğ, 1998).

\section{Tanı}

Hastalığın tanısında anamnez, klinik ve laboratuvar bulguları birlikte değerlendirilmelidir (Nelson, 1995). Kesin tanı anamnez ile birlikte hastalığa uyumlu klinik bulgular, hiperglisemi ve glikozürinin saptanması ile konulur (Lutz ve Rand, 1995; Nelson, 1995). Ancak tek başına glikoz seviyesinin ölçümü yeterli olmayabilir. Böyle durumlarda oral veya intravenöz glikoz tolerans testi yapılmalıdır (Aytuğ, 1998; Karagül ve ark. 2000; Turgut, 2000).

Hastalığın tanısında fruktozamin ve glikozlanmış hemoglobin (HbA1C) konsantrasyonlarından da yararlanılır (Catchpole ve ark. 2005). Bu testler kısa süreli stresten etkilenmediklerinden dolayı stres sonucu gelişebilecek hipergliseminin gerçek diyabet olgularında şekillenen hiperglisemiden ayırt edilmesinde değerlidir. (Turgut, 2000).

\section{Ayırıcı Tanı}

Hastalığın ayırıcı tanısında stres, hiperadrenokortisizm, primer renal glikozüri, pankreatitis, ekzokrin pankreatik neoplazi, diöstrus, renal yetmezlik, pheochromocytoma ve 
postprandial hiperglisemi gibi hastalık ve bozukluklar dikkate alınmalıdır. Hiperglisemi, primer renal glikozüride görülür. Glikozüri, diabetes mellitus'u hiperglisemiye neden olan renal yetmezlik, ekzokrin pankreatik neoplazi, pheochromocytoma, diöstrus, ve postprandial hiperglisemi gibi hastalıklardan ayırır.

\section{Sağaltım}

\section{Komplike olmayan diabetes mellitus}

Sağaltımdaki ana prensip, insülin noksanlığı veya insülin antagonizması ile oluşan katabolik etkileri tersine çevirmek ve protein, yağ, karbonhidrat metabolizmasında normal hemostatik dengeyi yeniden kurmaktır (Tablo 1). Komplike olmayan diabette bu amaçla günde bir veya iki kez 0,4-0,7 U/kg uzun ya da orta etkili insülin kullanılmalıdır (Lilley, 1988).

Tablo 1. Piyasada kullanılan insülin preparatları.

\begin{tabular}{lllcccc}
\hline İnsülin & Yol & $\begin{array}{l}\text { Etkinin } \\
\text { başlangıc1 }\end{array}$ & \multicolumn{2}{c}{$\begin{array}{c}\text { Etkinin pikte olduğu } \\
\text { dönem (saat) }\end{array}$} & \multicolumn{2}{c}{ Etki süresi (saat) } \\
\hline Glargine & & & Köpek & Kedi & Köpek & Kedi \\
NPH & SC & 1 Saat & $4-10$ & -- & 24 & 24 \\
Canİnsülin/Vetsulin & SC & 0,5-2 Saat & $2-10$ & $2-8$ & $6-18$ & $4-12$ \\
PZI & SC & 0,5-2 Saat & $2-10$ & -- & $8-20$ & -- \\
Regular & SC & 0,5-4 Saat & -- & $4-14$ & $4-10$ & $6-20$ \\
& IV & Hemen & $0,5-2$ & $0,5-2$ & $1-4$ & $1-4$ \\
& IM & 10-30 dak & $1-4$ & $1-4$ & $3-8$ & $3-8$ \\
& SC & 10-30 dak & $1-5$ & $1-5$ & $4-10$ & $4-10$ \\
\hline
\end{tabular}

Kan glikozu seviyesine göre gerekli insülin dozu ile tipi, uygulama aralığı ve gıda verilme zamanı değişebilir. Kan glikoz düzeyi ideal olarak sağaltım süresince 90-162 mg/dl arasında olmalıdır. Hastalarda sabah ilk idrar örneklerinde az miktarda glikozüri olabilir fakat gün içinde alınan diğer örneklerde glikozüri tespit edilmemelidir (Nelson, 1995; Schaer, 2003).

\section{Oral antidiyabetikler}

Sülfonilüreaz: Veteriner hekimlikte en yaygın kullanılan ilaç sülfonilüreaz glizipiddir. Bu ilaç pankreatik ß hücrelerinde plazma membranındaki ATP bağımlı potasyum (K)'u inhibe eder. Bu da depolarizasyon ve insülinin salınımıyla sonuçlanır. Sülfonilüreaz 5-10 mg'lık tabletler halinde bulunur. Glipizidin etkili olabilmesi için $\beta$ hücrelerinin hala insülin salgılayabilme kapasitesine sahip olması gerekir. Bu nedenle tedavide bu ilaç sadece insülin 
sekresyonunun belgelendiği (glukoz/glukojen stimülasyon testi vs) olgularında uygulanabilir (Fleeman ve Rand, 2001; Aytuğ, 2011).

\section{Diyet}

Tanı konulduğu andan itibaren hayvanın diyeti sabit tutulmalıdır. Kutulanmış yiyecekler protein, yağ, sindirilebilir karbonhidrat ve lif açısından sabit besin değerine sahiptir ve bu amaçla kullanılacak en kolay yöntemdir. Yiyeceklerin miktarı ve tipi insülin ihtiyacını direkt olarak etkiler. Diyet uygulanan bazı hastalar normal kilolarına indiklerinde insüline ihtiyaç göstermeyebilirler (Lilley, 1988; Ihle, 1995). Kronik pankreatitis sonucu gelişen DM'ta tabloya ekzokrin pankreatik yetersizlik de eklenebilir. $\mathrm{Bu}$ durumdaki hastalara sindirilebilirliği yüksek, az lifli yüksek karbonhidrat- düşük yağ ve yağda eriyen özellikle K vitamini içeren diyet önerilir. Hiperlipidemi ve hipertansiyon, sağaltılmayan ya da kontrolü iyi yapılamayan DM'lularda görülen komplikasyonlardandır. Hiperlipidemi için düşük yağyüksek oranda lif içeren diyet, hipertansiyon için kısıtlı $\mathrm{Na}$ ve yüksek lif içeren diyet düzenlemesi yapılmalıdır (Ihle, 1995).

\section{Dişi Köpekler}

Östrus ve gebelik dönemi hormonları insüline antagonist etki yaparlar. Bu nedenle köpeklerin gebe kalmaları mümkün olduğunca önlenmelidir. Östrus, gebelik, yalancı gebelik ile artan enerji ihtiyacı, hormonların antagonistik etkisi ve plasentanın salgıladığı insulinaz, ketoasidozin başlamasına yol açar. Bu problemlere sürekli yüksek kan glukozu nedeniyle, fötal büyüme hormonunun stimulasyonuna sekonder gelişen "fötüsun aşırı kilolu” olması hali de eklenebilir. Kronik hiperglisemi aynı zamanda fötus pankreası B-hücrelerinde hiperplaziye yol açar ve yeni doğan yavru ya da yavrularda hipoglisemik kriz riski oluşur (Lilley, 1988).

\section{Komplike olmuş diabetes mellitus}

Diabetik ketoasidozis, diabetes mellitus'ta görülebilen ciddi bir komplikasyondur ve acil müdahale gerektirir. Sağaltımda hedef sıvı-elektrolit kaybını düzelterek metabolizma düzenini yeniden oluşturmaktadır (Martin ve Rand, 2000; Özyener, 1998). Dehidrasyonu gidermek için serum fizyolojik veya Laktatlı Ringer gibi solüsyonlar damariçi verilmelidir (Fraser, 1986; Martin ve Rand, 2000; Rand ve ark. 2004; Schaer, 2003). Eğer oluşan metabolik asidoz şiddetli ise sodyum bikarbonat verilmelidir. Asidozis'te bikarbonat kullanımı eğer hızlı verilirse metabolik alkalosis, doku anoksisi ve paradoksik serebral asidozis gibi komplikasyonlara sebep olabildiğinden tartışmalıdır. (Fraser, 1986; Martin ve Rand, 2000). 


\section{Sonuç}

DM, ciddi bir hastalıktır; sağaltımı sabırlı ve istekli hayvan sahibi gerektirir. Çünkü köpeğin yaşamı boyunca monitörize edilmesi gerekir. Bu amaçla rutin injeksiyonlar, idrar ve kan glikoz düzeylerinin kontrol edilmesi, kaliteli hasta bakımı, günlük su/gıda tüketiminin takibi ve periyodik veteriner hekim ziyaretleri hasta sahiplerine anlatılmalıdır.

\section{Kaynaklar}

1. Aytuğ N. 1998. Metabolizma Hastalıkları, Kedi ve Köpek Hastalıkları, Medisan Yayınları, Ankara, 345-346.

2. Aytuğ N. 2011. Köpek ve Kedilerin İç Hastalıkları, 1. Bask1, F. Özsan Matbaac1l1k,Bursa, 370-378.

3. Başoğlu A, Sevinç M. 2004. Evcil Hayvanlarda Metabolik ve Endokrin Hastalıklar, Pozitif Matbaacilık, Konya.

4. Bush BM. 1991. Interprectation of Laboratory Results for Small Animal Clinicians, Blackwell Scientific Publications, London.

5. Catchpole B, Ristic JM, Fleeman LM, et al. 2005. Canine Diabetes Mellitus: can Old Dogs Teach us New Tricks? Diabetologia. 48 (10): 1948-1956.

6. Elliott DA, Nelson RW, Feldman EC, et al. 1997. Glycosylated Hemoglobin Concentration for Assesment of Glycemic Control in Diabetic Cats. J Vet Intern Med. 11, 3.

7. Ersöz B. 1990. Pankreas ve GI Traktus Hormonları, 22 Basım, Sistem Yayıncılık, İstanbul, 666-686.

8. Fleeman LM, Rand JS. 2001. Management of Canine Diabetes. Vet Clin North Am Small Anim Pract. 31 (5): 855-880.

9. Fraser CM. 1986. The Merck Veterinary Manual, Sixth edition, Mercand Co Inc., Rahway,USA, $165-177$

10. Guyton AC, Hall JE. 2000. Textbook of Medical Physilogy. 10th ed, WB Saunders, Philadelphia.

11. Hoenig M. 2002. comparative Aspects of Diabetes Mellitus in Dogs and Cats,Mol Cell Endocrinol, 221-229.

12. Ihle SL. 1995. Nutritional theraphy for diabetes mellitus, Vet Clin of North Am Small Anim Prac, 25, 585-594.
13. Karagül H, Fidancı UR, Altıntaş A, ve ark. 2000. Klinik Biyokimya, 1. Baskı, Medisan Yayınları, Ankara.

14. Lilley R. 1988. Diabetes Mellitus in Small Animals, Aust Vet Pract, 18, 22-30.

15. Lust E. 2002. Diabetes Mellitus in Canines and Felines. U.S Pharmacist. Vol. 27: 11.

16. Lutz TA, Rand JS. 1995. Pathogenesis of Feline Diabetes Mellitus. Veterinary Clinics of North America: Small Animal Practice. 25 (3): 527552.

17. Martin G, Rand J. 2000. Current Understanding of Feline Diabetes: Part 2, Treatment. Journal of Feline Medicine and Surgery. 2: 3-17.

18. Nelson RW. 1995. Diabetes Mellitus Veterinary Internal Medicine, 4.edition, W.B. Saunders Co., Philadelphia, 1510-1537.

19. Özyener F. 1998. Karbonhidrat Metabolizmas1. (Alınmıştır) Tıp Öğrencileri İçin Klinik Biyokimya, Ulukaya E (çeviri editörü). 1-20. Nobel\&Güneş Yayınları, Bursa.

20. Rand JS, Fleeman LM, Farrow HA. 2004. Canine and Feline Diabetes Mellitus Nature or Nuture.J Nutr.,134, 2072-2080.

21. Rand JS, Marshall RD. 2005. Diabetes Mellitus in Cats. Vet Clin North Am Small Anim Pract. $35,211-224$

22. Reusch CE, Tschour F, Kley S, et al. 2006. Diabetes Mellitus in the Cat: A Review. Schweiz Arch Tierheilkd. 148: 130-138.

23. Schaer M. 2003. Diabetes Mellitus, (in) Clinical Medicine of the Dog \& Cat. Manson Publishing Ltd,London.

24. Stogdale L. 1986. Definition of diabetes mellitus, Cornell Vet, 156-174.

25. Turgut K. 2000. Veteriner Klinik Laboratuar Teşhis.1. Baskı, Bahçıvanlar Basım Sanayi AŞ, Konya. 